\title{
POESÍA Y ANTIPOESÍA DE NICANOR PARRA
}

\author{
Manuel Silva Acevedo \\ mansilster@gmail.com
}

Aunque parezca obvio, para ser antipoeta primero hay que haber sido poeta y Nicanor Parra lo fue desde la publicación de Cancionero sin nombre (1937) hasta Poemas y antipoemas (1954), donde poemas como "Hay un día feliz", "Es olvido" o "Se canta al mar" denotan una marcada inspiración poética con pinceladas de antipoesía ("una tras otra en oleaje mudo/al establo volvían las ovejas. Las saludé personalmente a todas"), que los emparenta no tan lejanamente con el estro de un Pezoa Véliz, o de González Bastías, el poeta de las tierras pobres, sin ir más lejos.

Sin embargo, dichos poemas comienzan a ser desplazados en su pluma por los giros burlescos, humorísticos e irreverentes, que generan estupor entre aquellos que permanecen apegados a la tradición cuya rosa lírica a decir del antivate se "llena de piojos". Es así como sus antipoemas comienzan a subvertir el orden establecido.

El antipoeta no solo pone la belleza sobre sus rodillas, sino que le da palmadas en el trasero.

El lector queda advertido de que "la palabra arco iris no aparece en ninguna parte, menos aún la palabra dolor", que sí aparecerá como lo único real en el poema "El hombre imaginario" de los años 80.

A mi parecer, lo que ocurrió es que Nicanor Parra elaboró su propia estrategia de diferenciación con respecto a la presencia abrumadora de un Neruda que, hasta la aparición del nacido en Fabián de Alico, llenaba todo o casi todo el horizonte de la poesía nacional. Estratégicamente, el antipoeta se posicionó en las antípodas del "poeta oficial", por así decirlo, y desde su trinchera disparó a diestra y siniestra hasta no dejar títere con cabeza:

Hablando de peras, el antipoeta puede salir perfectamente con manzanas, sin que por eso el mundo se vaya a venir abajo. Y si se viene abajo, tanto mejor, esa es precisamente la finalidad última del antipoeta...

Todavía lejano su obsesivo interés por el príncipe Hamlet o el Rey Lear, en la postura parriana se advirtió desde un comienzo la impronta del teatro del absurdo de Ionesco con su Cantante calva, estrenada en 1950, de Esperando a Godot de Samuel Beckett -publicada en inglés en 1955-, o de Ubu Roi de Alfred Jarry, un precursor del absurdo. 
Asimismo, en su escritura y en su propia personalidad resalta un manifiesto componente histriónico, como se advierte en muchos de sus textos, especialmente en el Cristo de Elqui (1977), donde adopta este alter ego que le permite asestar aguijonazos como el bufón, el joker, en las barbas mismas del poder en plena dictadura.

Parra se instala de este modo como un espíritu burlón que se vale de la ironía y el no sense como una especie de mayéutica para producir en el lector o el espectador, en el caso de las "obras públicas", una suerte de shock que lo saque de una visión convencional y adocenada de la realidad. Por otra parte, sus artefactos parecieran ser una advertencia ante la manifiesta masificación de la sociedad contemporánea, en que el proceso de individuación y de alcanzar una identidad propia resulta cada vez más dificultoso y donde todo se deshumaniza y mercantiliza.

Sin embargo, es posible que haya habido en el Parra de los primeros entreveros con la poesía cierta añoranza de un mundo naïf, pícaro y popular como el del tío Roberto, o de la fuerza telúrica de su hermana Violeta, que se fue esfumando al convertirse el poeta - malgré lui- en un intelectual agudo y contestatario, taoísta y ecologista.

Como todo artista independiente y a la intemperie -como también se veía a sí mismo Enrique Lihn-, Parra ha jugado con sus propias reglas y conveniencias. Es por sobre todo un individualista, pero también tiene su corazoncito social (menos que Violeta, por cierto). A veces pudo haber sido visto como "políticamente sospechoso", pero Parra es Parra y esas nubes terminaron por disiparse ante el peso de su obra que está por encima del bien y del mal.

¿Pero quién salió perdiendo y quién salió ganando con la provocación del nuevo antipoeta, aunque no tan nuevo si recordamos que el propio Huidobro se definió como antipoeta y mago?

Está claro que a partir de Poemas y antipoemas, aquella poesía plagada de metáforas (o metaforones, como los llamó el mismo antipoeta) recibió su parte de defunción y hasta el mismo Neruda con su Estravagario (1958) acusó recibo del movimiento telúrico que estaba teniendo lugar bajo sus pies.

Más tarde, los poetas de la generación de los años 60 nos encontramos con la antipoesía parriana a la vuelta de la esquina (como anotó alguna vez Federico Schopf) y salimos ganando, porque la demolición de las formas caducas de hacer poesía ya estaba hecha y se nos abría todo un campo de acción que emprenderíamos con entusiasmo y dispar fortuna.

Para nosotros, poetas en crecimiento tenaz, como acotara Gonzalo Rojas, la antipoesía de Parra amplió las fronteras y abrió cauces a la cotidianidad y al lenguaje ciudadano común y silvestre. Por si fuera poco, contamos con la cercanía y la intermediación de entrañables poetas de los años cincuenta, como fueron Lihn, Rubio, Uribe, Teillier y Barquero, que ya habían asimilado y filtrado, cada uno a su modo particular, el proceso de renovación de la poesía chilena emprendida por Parra, acercándola al lector en un tono vivencial, coloquial e íntimo. Pienso que estos poetas rescataron la poesía del efecto devastador que la antipoesía parriana pudo llegar a tener en sus epígonos.

Ahora, con relación al giro que fue tomando la antipoesía de Parra en su evo(invo) lución, pareciera que el prurito de mantener una postura irreverente e iconoclasta fue 
derivando hacia el humor fácil y el ingenio dudoso, convirtiendo el uso y abuso de este recurso en su propia (anti)retórica.

Quizás el poema "El hombre imaginario" de 1980 sea una de sus últimas composiciones, si no la última, en que la poesía y la antipoesía unidas no son vencidas. 